\title{
Synthesis, crystal and molecular structure of manganese (II) complex of 2-acetylpyridine $\mathbf{N}(4)$ ethylthiosemicarbazone
}

\author{
${ }^{1}$ Felicite Majoumo-Mbe, ${ }^{1}$ Dieudonne T. Nde, ${ }^{1}$ Irene N. Mukoko, ${ }^{2}$ Offiong E. Offiong, ${ }^{1}$ Emmanuel N. \\ Nfor* \\ 1Department of Chemistry, Faculty of Science, University of Buea, PO Box 63 Buea, Cameroon \\ ${ }^{2}$ Department of Pure \& Applied Chemistry, University of Calabar, PO Box 1115 Calabar, CRS, Nigeria.
}

Corresponding Author*: nforemman@gmail.com

Received: December 14, 2015; accepted: February 05, 2016

\begin{abstract}
A novel $\mathrm{Mn}$ (II) complex with thiosemicarbazone derived from 2-acetylpyridine and N(4)-ethylthiosemicarbazide has been prepared. The single-crystal X-ray analysis of the Mn (II) complex showed a distorted octahedral $\mathrm{MnN}_{4} \mathrm{~S}_{2}$ environment with the ligand chelating via the nitrogen and sulfur donor atoms in a tridentate manner. The triclinic form of the ligand which has crystallized in a monoclinic system in other works is also described. The basicity of nitrogen atoms of the ligand was tested with its reaction with $\mathrm{HNO}_{3}$ and the structure of the salt obtained is reported. The result shows that the lone pair of the pyridine nitrogen is more available due to the delocalization of other nitrogen lone pair of electron.
\end{abstract}

Keywords: Thiosemicarbazone, 2-acetylpyridine, manganese (II) complex, crystal structures, basicity of nitrogen atoms.

\section{INTRODUCTION}

Heterocyclic thiosemicarbazones and their transition metal complexes have received considerable attention due to their coordination chemistry and broad range of pharmacological properties, notable for antiparasital, antibacterial and antitumor activities [1-6]. In addition the use of multidentate thiosemicarbazone as a general route for the construction of multimetallic helicates have recently been reported on, in which case the strategy demonstrated that the self -assembly can be perfectly controlled using a dianionic helicand thiosemicarbazone ligand equipped with two soft donor atoms [7].

Futhermore the structural diversity of thiosemicarbazide-based compounds is considerably increased not only due to the condensation of the different carbonyls but also due to the alkylation of the different parts of the thiosemicarbazide moiety [8]. The presence of akyl groups at the terminal N(4) postion on the thiosemicarbazone chain can considerably increase the activity [9]. A small number of metal complexes of 2-acetylpyridine $\mathrm{N}$ (4)ethyl thiosemicarbazone have been reported [8] in literature.

Manganese is an essential trace element forming the active sites of a number of matalloproteins. In these metalloproteins, man- ganese can exist in any of the five oxidation states (0, I, II, III, IV) or in mixed valence states [10]. Manganese has a vital role in many enzymatic systems in which mononuclear manganese active centers are present [11]. However, in spite of all these versatile applications, there appears only a very few reports on manganese (II) complexes of thiosemicarbazones derivatives [12]. In view of the above, this work reports the synthesis and structural characterization of manganese (II) complex of 2acetylpyridine $N(4)$ ethylthiosemicarbazone. The structure of the salt obtained from the reaction of the ligand with $\mathrm{HNO}_{3}$ is also reported.

\section{EXPERIMENTAL}

\subsection{Materials and equipment}

2-acetylpyridine, $N(4)$-ethyl thiosemicarbazide, $\mathrm{MnCl}_{2} \bullet 4 \mathrm{H}_{2} \mathrm{O}$ were used as supplied. The solvent used throughout the synthesis was distilled ethanol. The molar conductance measurement of the Mn complex in DMF solution $\left(10^{-3} \mathrm{M}\right)$ at room temperature was done using a direct reading conductivity meter. The infrared spectra were recorded on a Perkin-ELMER System 2000 FT - IR spectrometer scanning between 400 and $4000 \mathrm{~cm}^{-}$ ${ }^{1}$ using $\mathrm{KBr}$ pellets. The mass spectra were recorded on a FT-IR -MS Bruker-Dalton ESI spectrometer (APEX II, 7 Tesla). The elemental analyses were recorded on a VARIO EL (Heraeus). The melting points were determined in sealed capillaries with a Gallenkamp instrument and are uncorrected.

The crystallographic data were collected on a Gemini diffractometer (Agilent Technologies) using Mo-K $\alpha$ radiation ( $1=$ $71.073 \mathrm{pm}), \omega$-scan rotation. Data reduction was performed with the CrysAlis [13] including the program SCALE3 ABSPACK [14] for empirical absorption correction. The structure was solved by direct methods (SHELXS-97) and the refinement of all non-hydrogen atoms was performed with SHELXL-97 [15]. All non-hydrogen atoms were refined with anisotropic thermal parameters. For $\mathbf{1}$ and $\mathbf{2}$ a difference-density Fourier 
map was used to locate all Hydrogen atoms whereas for $\mathbf{3}$, excluding $\mathrm{H}(1 \mathrm{~N} 4)$ and $\mathrm{H}(1 \mathrm{~N} 8)$ all hydrogen atoms are calculated.

\subsection{Synthesis of compound $\mathbf{1}$ and $\mathbf{2}$}

The ligand 2-acetylpyridine N(4)-ethylthiosemicarbazone (1) was synthesised according to literature [16-17]. The single crystal suitable for X-ray diffraction was obtained in the filtrate from the synthesis of the $\mathrm{Mn}$ (II) complex. Compound $\mathbf{2}$ was obtained from the equimolar reaction of 1 with $\mathrm{HNO}_{3}$ in ethanol and was characterized by X-ray diffraction.

\subsection{Synthesis of the Mn(II) thiosemicarbazone complex 3}

A solution of $\mathrm{MnCl}_{2} \bullet 4 \mathrm{H}_{2} \mathrm{O}(0.5 \mathrm{~g}, 0.0025$ mole $)$ dissolved in ethanol $(10 \mathrm{ml})$ were added drop-wise to a stirred solution of 2acetylpyridine $N(4)$-ethylthiosemicarbazone $\quad(1.11 \mathrm{~g}, 0.005$ mole) dissolved in ethanol. The resulting solution was refluxed for four hours. The orange precipitate formed was filtered, washed with methanol and dried. Yield: $0.75 \mathrm{~g}$, (60 \%); m.p. 210-212 ${ }^{\circ} \mathrm{C}$. IR (KBr): v (O-H) $3439 \mathrm{~cm}^{-1}, v(\mathrm{~N}-\mathrm{H}) 3252 \mathrm{~cm}^{-1}, v$ (C-H) $3052 \mathrm{~cm}^{-1}, 2980 \mathrm{~cm}^{-1}, v(\mathrm{C}=\mathrm{N}) 1566 \mathrm{~cm}^{-1}, 1473 \mathrm{~cm}^{-1}$, $1440 \mathrm{~cm}^{-1}, v(\mathrm{C}-\mathrm{S}) 1385 \mathrm{~cm}^{-1}, 1255 \mathrm{~cm}^{-1}, 1109 \mathrm{~cm}^{-1}, 777 \mathrm{~cm}^{-1}$, $640 \mathrm{~cm}^{-1}, 559 \mathrm{~cm}^{-1}, 451 \mathrm{~cm}^{-1}$. MS (ESI): $\mathrm{m} / \mathrm{z}=498\left(\mathrm{M}^{+}, 100\right.$ \%). Elemental analysis: $\mathrm{C}_{20} \mathrm{H}_{26} \mathrm{MnN}_{8} \mathrm{~S}_{2} \cdot 2 \mathrm{H}_{2} \mathrm{O}$ (533.55); C 44.61 (44.98), H 5.73 (5.62), N 21.04 (20.99) \%.

\section{RESULTS AND DISCUSSION}

\subsection{IR analysis}

In manganese (II) complex $\mathbf{3}$ the thiosemicarbazone ligand $\mathbf{1}$ deprotonates and chelates in the thiolate form as proved by the shift of the $\mathrm{C}=\mathrm{S}$ vibration band in the ligand from $1533 \mathrm{~cm}^{-1}$ to $\mathrm{C}=\mathrm{S}$ in the complex at $1385 \mathrm{~cm}^{-1}$. The molar conductivity measurement in $10^{-3} \mathrm{M}$ DMF solution gave a molar conductance of $10 \mathrm{ohm}^{-1} \mathrm{~cm}^{2} \mathrm{~mol}^{-1}$; indicating that the complex is nonelectrolyte.

The strong band in the spectrum of ligand 1 at $3350 \mathrm{~cm}^{-1}$ assigned to $(\mathrm{N}-\mathrm{H})$ vibration is not present in the IR spectrum of the $\mathbf{3}$, indicating the deprotonation of the ligand in its reaction with the metal ion. The $(\mathrm{C}=\mathrm{N})$ and the $(\mathrm{C}=\mathrm{S})$ vibrations of the ligand are shifted from1581 and $1533 \mathrm{~cm}^{-1}$ to lower values of 1566 and $1385 \mathrm{~cm}^{-1}$ respectively upon coordination. Similar shifts have been observed in others thiosemicarbazone complexes of manganese [11, 18-19]. This indicated that the ligand is coordinated to the central metal ion through the azomethine nitrogen. The involvement of this nitrogen in bonding is also supported by a shift in $v(\mathrm{~N}-\mathrm{N})$ from $1085 \mathrm{~cm}^{-1}$ in the free ligand to higher frequency $\left(1109 \mathrm{~cm}^{-1}\right)$ in the complex. The large negative shift of the $v(\mathrm{C}=\mathrm{S})$ band indicates the change in the bond order and the coordination of the ligand via the thiolate sulphur to manganese atom.

The coordination of the nitrogen atom of pyridine ring to the $\mathrm{Mn}(\mathrm{II})$ ion in complex $\mathbf{3}$ is indicated by the shift of the pyridine ring vibration of the ligand $\left(551 \mathrm{~cm}^{-1}\right)$ to higher frequency (559 $\mathrm{cm}^{-1}$ ) in its manganese complex. Similar shifts have been observed in other manganese complex [11,20-21] upon coordination of the pyridine ring to the metal centre. From the ESI mass spectrum of complex 3 , the parent ion peak indicates that the metal complex was formed in a 2:1 ligand to metal ratio.

Scheme 1: Formation of compound 2
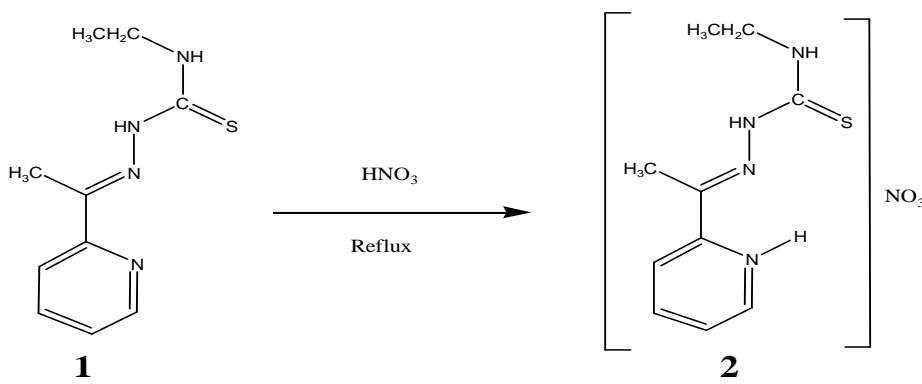

\subsection{Molecular structure of 1, 2 and 3}

Pale yellow crystals of $\mathbf{1}$ suitable for X-ray diffraction were obtained from the filtrate in the synthesis of $\mathbf{3}$.

Compound 1 (Fig. 1) crystallizes in the triclinic system, in the space group $P \overline{1}$, with two independent molecules in the asymmetric unit in a slightly different conformation. Compound $\mathbf{1}$ can react with $\mathrm{HNO}_{3}$ when present in solution with the protona-

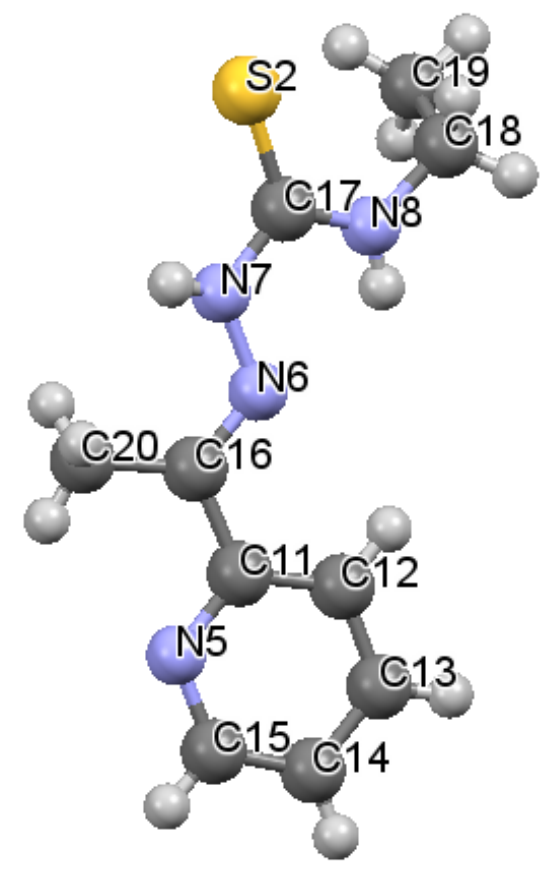

Figure 1: Molecular structure of 1 
tion of the pyridine nitrogen as observed in the formation of compound 2 (Scheme 1). Similar reactions $[10,22]$ has been reported with $\mathrm{HCl}$ in thiosemicarbazone solution. Compound 2 (Fig. 3) crystallizes in a monoclinic system; in the space group $P 2_{1} / \mathrm{n}$. Selected bond lengths and angles and crystal data for $\mathbf{1}$, $\mathbf{2}$ and $\mathbf{3}$ are listed in Tables 1 and 2 respectively.
The structure of $\mathbf{1}$ had earlier been reported [10,23] in which case it crystallized in the monoclinic system, with space group $P 2_{1} / \mathrm{n}$. The bond distances $\mathrm{C}(7)-\mathrm{S}(1)$ [1.691(2) and $\mathrm{N}$ (2)-C(6) $[1.289(2)]$ are similar to those found in the monoclinic structure of [1.676(2) and 1.287(2)] [10] respectively.

Table 1: Selected bond lengths $(\AA)$ and angles $\left({ }^{\circ}\right)$ for $\mathbf{1}, \mathbf{2}$ and 3

\begin{tabular}{|c|c|c|c|}
\hline Bond lengths & 1 & 2 & 3 \\
\hline $\mathrm{N}(3)-\mathrm{C}(7) / \mathrm{N}(7)-\mathrm{C}(17)$ & $1.360(2) / 1.361(2)$ & $1.373(2)$ & $1.341(2) / 1.324(2)$ \\
\hline$S(1)-C(7) / S(2)-C(17)$ & $1.691(1) / 1.694(1)$ & $1.682(1)$ & $1.733(2) / 1.747(2)$ \\
\hline $\mathrm{N}(1)-\mathrm{C}(1) / \mathrm{N}(5)-\mathrm{C}(11)$ & $1.343(2) / 1.342(2)$ & $1.350(2)$ & $1.349(2) / 1.347(2)$ \\
\hline $\mathrm{N}(2)-\mathrm{N}(3) / \mathrm{N}(6)-\mathrm{N}(7)$ & $1.381(2) / 1.378(2)$ & $1.354(2)$ & $1.369(2) / 1.365(2)$ \\
\hline $\mathrm{N}(2)-\mathrm{C}(6) / \mathrm{N}(6)-\mathrm{C}(16)$ & $1.289(2) / 1.286(2)$ & $1.291(2)$ & $1.299(2) / 1.300(2)$ \\
\hline $\mathrm{N}(3)-\mathrm{H} / \mathrm{N}(7)-\mathrm{H}$ & $0.890(2) / 0.867(2)$ & $0.884(2)$ & \\
\hline $\mathrm{N}(4)-\mathrm{H} / \mathrm{N}(8)-\mathrm{H}$ & $0.850(2) / 0.854(2)$ & $0.869(2)$ & $0.93(3) / 0.87(2)$ \\
\hline $\mathrm{N}(1)-\mathrm{H}$ & & $0.860(2)$ & \\
\hline $\mathrm{Mn}-\mathrm{N}(5)$ & & & $2.251(2)$ \\
\hline $\mathrm{Mn}-\mathrm{N}(6)$ & & & $2.258(2)$ \\
\hline $\mathrm{Mn}-\mathrm{N}(1)$ & & & $2.283(2)$ \\
\hline $\mathrm{Mn}-\mathrm{N}(2)$ & & & $2.251(2)$ \\
\hline $\mathrm{Mn}-\mathrm{S}(2)$ & & & $2.524(5)$ \\
\hline $\mathrm{Mn}-\mathrm{S}(1)$ & & & $2.522(5)$ \\
\hline \multicolumn{4}{|l|}{ Bond angles } \\
\hline $\mathrm{C}(6)-\mathrm{N}(2)-\mathrm{N}(3) / \mathrm{C}(16)-\mathrm{N}(6)-\mathrm{N}(7)$ & $117.71(1) / 117.48(1)$ & $118.88(1)$ & \\
\hline $\mathrm{C}(7)-\mathrm{N}(3)-\mathrm{N}(2) / \mathrm{C}(17)-\mathrm{N}(7)-\mathrm{N}(6)$ & 117.51(1) / 118.46(1) & $119.80(1)$ & \\
\hline $\mathrm{C}(7)-\mathrm{N}(4)-\mathrm{C}(8) / \mathrm{C}(17)-\mathrm{N}(8)-\mathrm{C}(18)$ & $124.53(1) / 124.45(1)$ & $124.80(1)$ & \\
\hline $\mathrm{N}(4)-\mathrm{C}(7)-\mathrm{N}(3) / \mathrm{N}(8)-\mathrm{C}(17)-\mathrm{N}(7)$ & $116.14(1) / 117.08(1)$ & $116.65(1)$ & \\
\hline $\mathrm{N}(4)-\mathrm{C}(7)-\mathrm{S}(1) / \mathrm{N}(8)-\mathrm{C}(17)-\mathrm{S}(2)$ & 124.15(1)/ 123.91(1) & $125.55(9)$ & \\
\hline $\mathrm{N}(3)-\mathrm{C}(7)-\mathrm{S}(1) / \mathrm{N}(7)-\mathrm{C}(17)-\mathrm{S}(2)$ & 119.64(1) / 119.01(1) & $117.79(9)$ & \\
\hline $\mathrm{N}(2)-\mathrm{Mn}-\mathrm{N}(5)$ & & & $112.08(6)$ \\
\hline $\mathrm{N}(2)-\mathrm{Mn}-\mathrm{N}(6)$ & & & $158.77(5)$ \\
\hline $\mathrm{N}(5)-\mathrm{Mn}-\mathrm{N}(6)$ & & & $71.58(5)$ \\
\hline $\mathrm{N}(5)-\mathrm{Mn}-\mathrm{N}(1)$ & & & $91.02(6)$ \\
\hline $\mathrm{N}(2)-\mathrm{Mn}-\mathrm{S}(1)$ & & & $76.26(4)$ \\
\hline $\mathrm{N}(5)-\mathrm{Mn}-\mathrm{S}(1)$ & & & $88.39(4)$ \\
\hline $\mathrm{N}(6)-\mathrm{Mn}-\mathrm{S}(1)$ & & & $124.97(4)$ \\
\hline $\mathrm{N}(1)-\mathrm{Mn}-\mathrm{S}(1)$ & & & $145.23(4)$ \\
\hline $\mathrm{N}(2)-\mathrm{Mn}-\mathrm{S}(2)$ & & & $102.02(4)$ \\
\hline $\mathrm{N}(6)-\mathrm{Mn}-\mathrm{S}(2)$ & & & $75.38(4)$ \\
\hline $\mathrm{N}(1)-\mathrm{Mn}-\mathrm{S}(2)$ & & & $96.45(4)$ \\
\hline $\mathrm{S}(1)-\mathrm{Mn}-\mathrm{S}(2)$ & & & $103.40(2)$ \\
\hline
\end{tabular}


The intermolecular hydrogen bonds $\mathrm{N}(4)-\mathrm{H}---\mathrm{S}(2), \mathrm{N}(8)-\mathrm{H}---\mathrm{S}$ (1) in the triclinic structure of $\mathbf{1}$ are detectable (Table 3). However, relatively weak N-H---S donor acceptor bonds are found in both triclinic and monoclinic forms of $\mathbf{1}$. Taking these interactions into account, a two dimensional layer structure of the triclinic ligand $\mathbf{1}$ along [011] is formed (Fig.3a).
The molecular structure of compound 2 (Fig. 3a) reveals that there are $\mathrm{N}-\mathrm{H}----\mathrm{O}$ hydrogen donor acceptor bonds interaction between the nitrate anion and the cationic ligand through the $\mathrm{N}$ (4) $\mathrm{H}$ and the pyridine $\mathrm{N}(1) \mathrm{H}$ as depicted in Fig. 3b below. The bond distances and angles observed for 2 are similar to those obtained in the monoclinic form [23] of the thiosemicarbazone ligand 1.

Table 2: Selected crystallographic and refinement data for $\mathbf{1 , 2}$ and $\mathbf{3}$

\begin{tabular}{|c|c|c|c|}
\hline Compounds & 1 & 2 & 3 \\
\hline Empirical formula & $\mathrm{C}_{10} \mathrm{H}_{14} \mathrm{~N}_{4} \mathrm{~S}$ & {$\left[\mathrm{C}_{10} \mathrm{H}_{15} \mathrm{~N}_{4} \mathrm{~S}\right] \mathrm{NO}_{3}$} & $\mathrm{C}_{20} \mathrm{H}_{26} \mathrm{MnN}_{8} \mathrm{~S}_{2}$ \\
\hline Formula weight & 222.31 & 285.33 & 497.55 \\
\hline Temperature/K & $130(2)$ & $130(2)$ & $130(2)$ \\
\hline Crystal system & Triclinic & Monoclinic & Monoclinic \\
\hline Space group & $P \overline{1}$ & $P 2_{1} / \mathrm{n}$ & $P 2_{1}$ \\
\hline \multicolumn{4}{|l|}{ Unit cell dimensions } \\
\hline a $(\AA)$ & $9.7697(6)$ & $4.4434(2)$ & $8.7352(4)$ \\
\hline $\mathrm{b}(\AA)$ & $9.9448(6)$ & $14.5223(8)$ & $14.7050(6)$ \\
\hline c $(\AA)$ & $12.3579(10)$ & $20.3917(12)$ & $9.2896(4)$ \\
\hline$\alpha$ & $87.711(6)^{\circ}$ & $90^{\circ}$ & $90^{\circ}$ \\
\hline$\beta$ & $83.373(6)^{\circ}$ & $93.584(5)^{\circ}$ & $102.050(4)^{\circ}$ \\
\hline$\gamma$ & $74.738(5)^{\circ}$ & $90^{\circ}$ & $90^{\circ}$ \\
\hline Volume & $1150.52(14) \AA^{3}$ & $1313.27(12) \AA^{3}$ & $1166.97(9) \AA^{3}$ \\
\hline $\mathrm{Z}$ & 4 & 4 & 2 \\
\hline Absorption coefficient & $0.255 \mathrm{~mm}^{-1}$ & $0.259 \mathrm{~mm}^{-1}$ & $0.769 \mathrm{~mm}^{-1}$ \\
\hline$\Theta_{\min } / \Theta_{\max }$ & $2.95 / 30.51^{\circ}$ & $2.98 / 36.32^{\circ}$ & $2.91 / 30.51^{\circ}$ \\
\hline Reflections collected & 13420 & 23114 & 19824 \\
\hline Independent reflections & 7007 & 6375 & 7040 \\
\hline $\mathrm{R}_{\text {int }}$ & 0.0250 & 0.0463 & 0.0379 \\
\hline Restraints/parameters & $30 / 383$ & $0 / 232$ & $1 / 293$ \\
\hline $\mathrm{R}(\mathrm{I}>2 \sigma(\mathrm{I}))$ & 0.0416 & 0.0525 & 0.0399 \\
\hline wR2(all data) & 0.1082 & 0.1254 & 0.0627 \\
\hline
\end{tabular}

Table 3: Hydrogen bonds for $\mathbf{1}\left[(\AA)\right.$ and $\left.{ }^{\circ}\right]$.

\begin{tabular}{ccccc}
\hline $\mathrm{D}-\mathrm{H} . . . \mathrm{A}$ & $\mathrm{d}(\mathrm{D}-\mathrm{H})$ & $\mathrm{d}(\mathrm{H} \ldots \mathrm{A})$ & $\mathrm{d}(\mathrm{D} \ldots \mathrm{A})$ & $<(\mathrm{DHA})$ \\
\hline $\mathrm{N}(3)-\mathrm{H}(1 \mathrm{~N} 3) \ldots \mathrm{S}(1) \# 1$ & $0.887(19)$ & $2.576(19)$ & $3.4114(13)$ & $157.2(15)$ \\
$\mathrm{N}(4)-\mathrm{H}(1 \mathrm{~N} 4) \ldots \mathrm{S}(2) \# 2$ & $0.846(19)$ & $2.720(19)$ & $3.3801(13)$ & $136.0(15)$ \\
$\mathrm{N}(7)-\mathrm{H}(1 \mathrm{~N} 7) \ldots \mathrm{S}(2) \# 3$ & $0.867(17)$ & $2.637(17)$ & $3.4693(13)$ & $161.3(15)$ \\
$\mathrm{N}(8)-\mathrm{H}(1 \mathrm{~N} 8) \ldots \mathrm{S}(1) \# 1$ & $0.854(19)$ & $2.897(18)$ & $3.4907(13)$ & $128.3(15)$ \\
\hline
\end{tabular}

Symmetry transformations used to generate equivalent atoms: \#1 -x,-y+3,-z+1

$\# 2-x,-y+2,-z+1 \quad \# 3-x,-y+2,-z$ 
Compound 3 crystallized in the monoclinic system in the space group $P 2_{1}$ with two molecules in the unit cell. The molecular structure of $\mathbf{3}$ (Fig. 4) indicates from the bond angles a distorted octahedral geometry for the compound. The two molecule of the

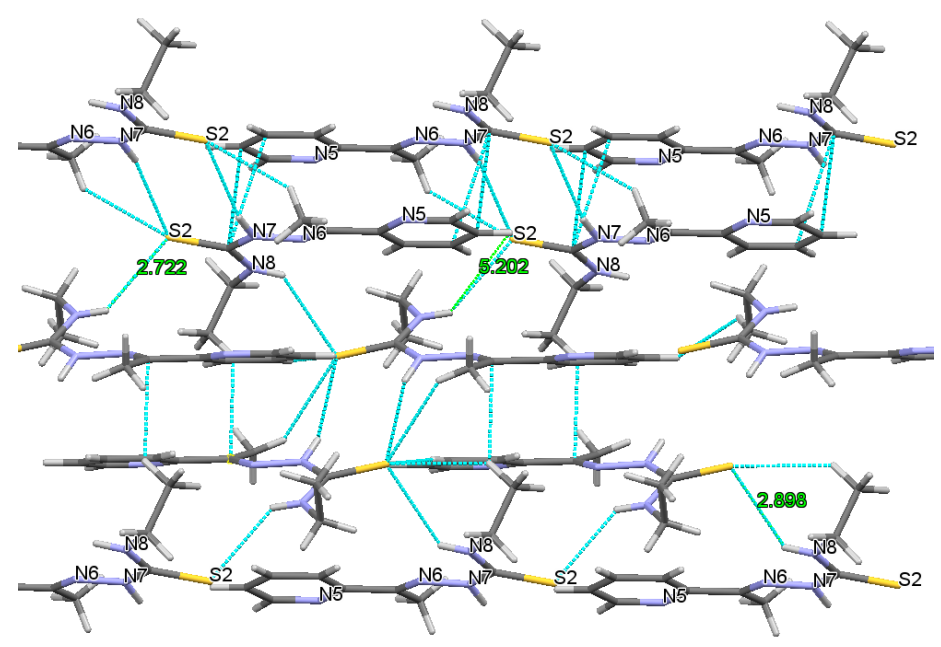

Figure 2: Packing diagram of 1

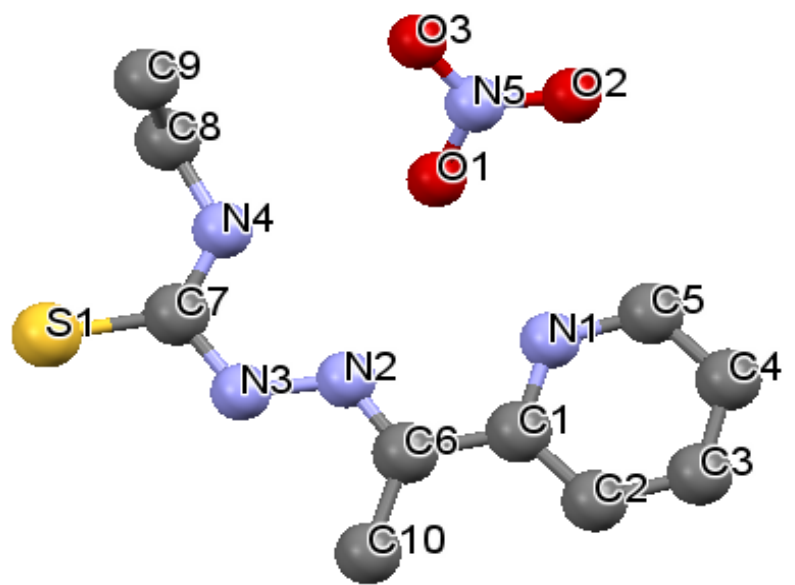

Figure 3a: Molecular structure of 2

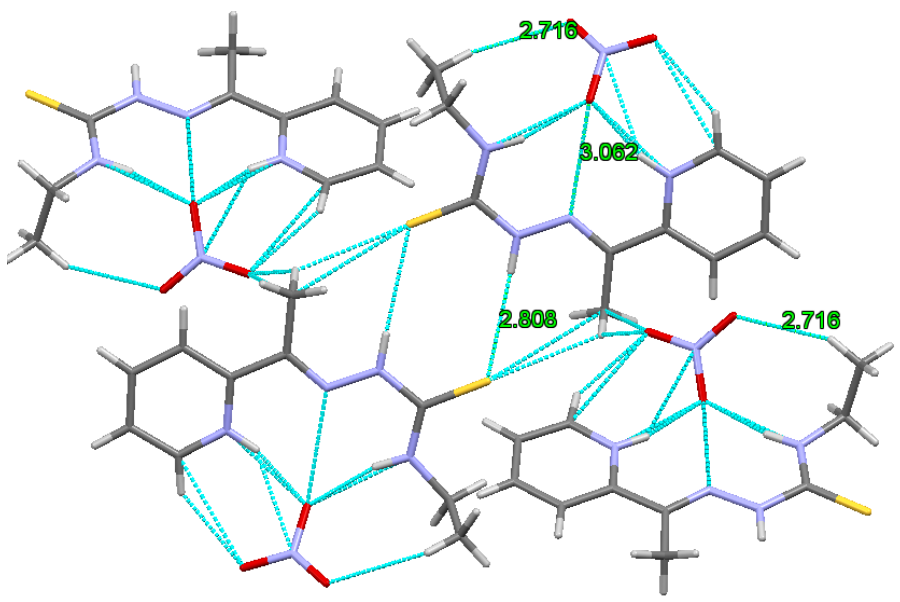

Figure 3b: Hydrogen bonding interaction in $\mathbf{2}$

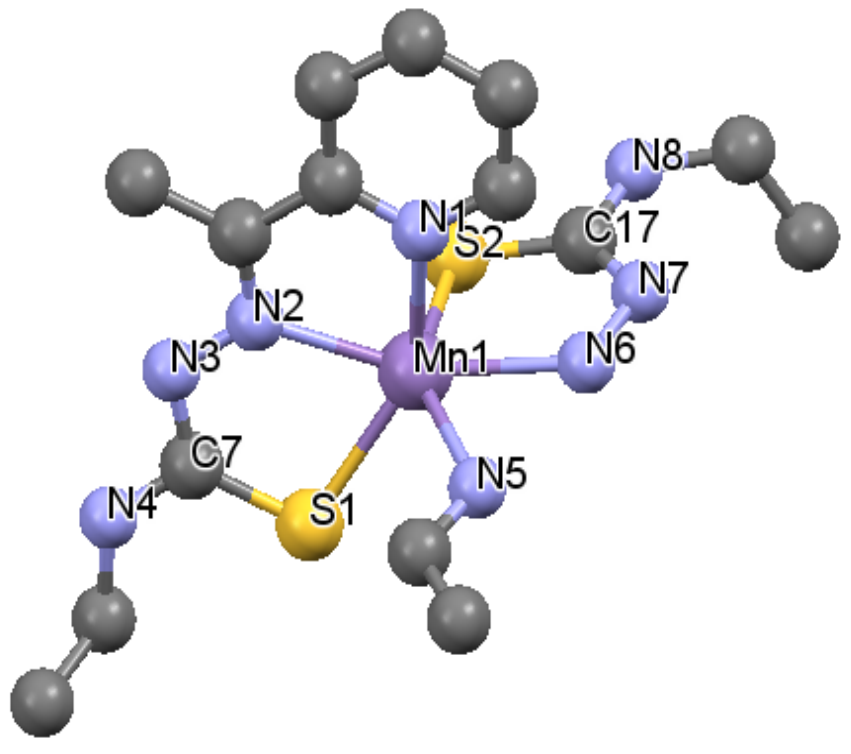

Figure 4: Coordination environment of $\mathbf{3}$

deprotonated ligand coordinate to the manganese in a $\mathrm{N}_{4} \mathrm{~S}_{2}$ manner, through the pyridine nitrogen, the azomethine nitrogen and the thiolato sulfur atoms to form four membered chelate rings. With the exception of C9 (first ligand) and C19 (second ligand), all atoms of each ligand are $\pm 0.1 \AA$ with in the plane, indicating the almost planar geometry of the whole coordinating ligand. The angle between the planes formed by the two ligands is $79.99(3)^{\circ}$, indicating a distorted octahedral coordination geometry, which ideally should be $90^{\circ}$ for a regular octahedral environment.

The coordination of the sulfur occurs through deprotonation after enolization, and was confirmed by the partial single and the double bond nature of C(7)-S(1) [1.733(2) $\AA$ ], C(17)-S(2) [1.747(2) $\AA$ and N(3)-C(7) [1.341(2) $\AA, \mathrm{N}(7)-\mathrm{C}(17)$ [1.324(2) $\AA$ ) bonds as has been reported for other manganese complexes with thiosemicabazone [21-22] in a similar environment. On coordination to the metal ion, the ligand undergoes structural reorientation. This suggests that a possible rotation around N3C7 with a double bond character occurs on coordination so that the pyridine nitrogen would be in the position to coordinate.

The Mn- $\mathrm{N}_{\text {azomethine }}$ average bond distance of $2.25 \AA$ is shorter than the Mn-Npyridine average bond distance of $2.27 \AA$, which may be attributed to the fact that the azomethine nitrogen is a stronger base compared with the pyridyl nitrogen. The Mn-S(1) and $\mathrm{Mn}-\mathrm{S}(2)$ average bond length of $2.52 \AA$ are larger than the Mn-N azomethine bond length. These comparatively larger bond lengths are indicative of weak bonding of the ligand to the metal $[9,20]$. Furthermore S-donors are softer compare to $\mathrm{N}$ donors.

The $\mathrm{C}(7)-\mathrm{N}(3)-\mathrm{N}(2)$ and the $\mathrm{C}(17)-\mathrm{N}(7)-\mathrm{N}(6)$ bond angles of $117.5(1)^{\circ}$ and $118.5(2)^{\circ}$ in the free ligand reduced to $113.8(1)^{\circ}$ and $113.7(2)^{\circ}$ in the complex as the consequence of the bonding to the metal. A similar observation has been previously reported 
Table 4: Hydrogen bonds for 3 [( $\AA$ ) and $\left.{ }^{\circ}\right]$.

\begin{tabular}{lcccc} 
D-H...A & $\mathrm{d}(\mathrm{D}-\mathrm{H})$ & $\mathrm{d}(\mathrm{H} \ldots \mathrm{A})$ & $\mathrm{d}(\mathrm{D} \ldots \mathrm{A})$ & $<$ (DHA) \\
\hline $\mathrm{N}(8)-\mathrm{H}(1 \mathrm{~N} 8) \ldots \mathrm{N}(3) \# 1$ & $0.87(2)$ & $2.28(3)$ & $3.129(2)$ & $167(2)$ \\
$\mathrm{N}(4)-\mathrm{H}(1 \mathrm{~N} 4) \ldots \mathrm{S}(2) \# 2$ & $0.93(3)$ & $2.41(3)$ & $3.342(2)$ & $173(2)$ \\
\hline
\end{tabular}

Symmetry transformations used to generate equivalent atoms:

$\# 1-x+1, y+1 / 2,-z+2, \# 2-x+1, y-1 / 2,-z+2$

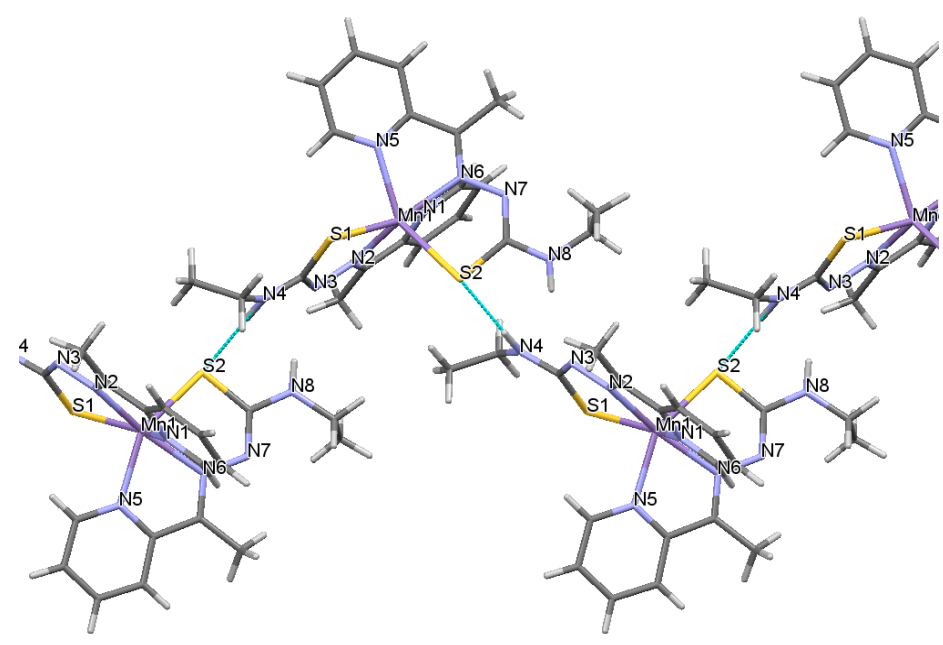

Figure 5a: Packing diagram of $\mathbf{3}$ along b-axis

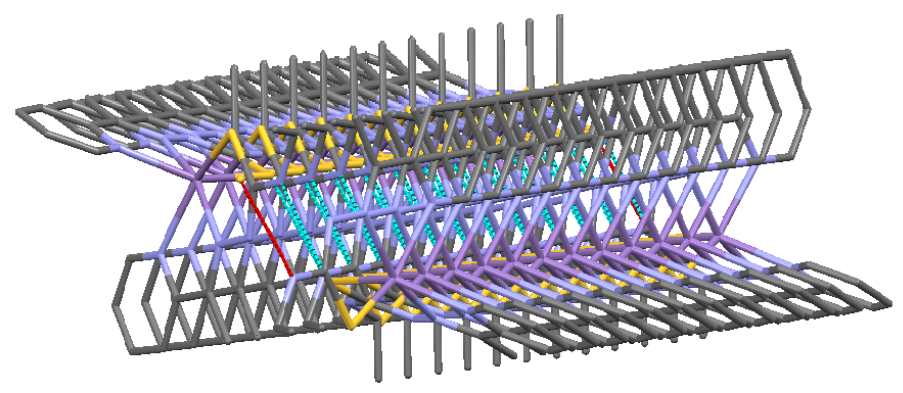

Figure 5b: Schematic representation of 2D sheet of $\mathbf{3}$

with manganese complex of other thiosemicarbazone ligands $[11,22]$.

The packing diagram of 3 (Fig.5a) shows that the molecules are connected in the crystal lattice through some intermolecular hydrogen donor acceptor bonds (Table 4), that forms a zigzag chain along b-axis. This intermolecular hydrogen bonds further lead to a self-assembly process (Fig.5b) that can perfectly be controlled as earlier reported [21]. Compound 3 is a peculiar self-threading. It is believed that the N(4)ethylphenyl groups of the thiosemicarbazone have a very important influence on the formation of self threading. In other words the bulky ethyl phenyl groups of the thiosemicarbazone provide a potential condition for the formation of the self-threading and polythreading.

\section{CONCLUSION}

We have synthesized and characterized by X-ray diffraction, infrared, elemental analysis and mass spectrum a novel manganese (II) complex of 2-acetylpyridine-N (4) ethylthiosemicarbazone. The triclinic form of the Ligand which has earlier been reported as monoclinic by others has been found to chelate to the metal center in a tridentate fashion with the manganese (II) complex adopting a distorted octahedral geometry.

\section{Supplementary Material}

CCDC 1007672, 1007673 and 1009079 contains the supplementary crystallographic data for this paper. These data can be obtained free of charge via www.ccdc.cam.ac.uk/data_request/ cif (or from the Cambridge Crystallographic Data Centre, 12 Union Road, Cambridge CB2 1EZ, UK; fax: (+44)1223-336033; or deposit@ @cdc.cam.uk).

\section{Acknowledgements}

ENN is thankful to TWAS for post-doctoral fellowship and Professors You Xiao-Zeng and Zuo Jing-Lin of the Coordination Chemistry Institute, Nanjing University, China for hosting the fellowship while, FMM is thankful to Prof. Dr. Evamarie HeyHawkins of the Institute of Inorganic Chemistry, University of Leipzig, Germany for providing us X-ray, MS and IR analysis.

\section{REFERENCES}

[1] Karp, J. E.; Giles, F. J.; Gojo I, Morris L.; Greer J.; Johnson B.; Thein M.; Sznol M.; Low J. Leuk. Res. 2008, 32, 71.

[2] West, D. X.; Liberta, A. E.; Padhye S. B.; Chikate, R. C.; Sonawane, P. B.; Kumbhar, A. S.; Xerande, R. G. Coord. Chem. Rev. 1993 123, 49.

[3] Murugkar, A.; Padhye, S.; Guha-Roy, S.; Wagh, U. Inorg. Chem. Commun. 1999, 2, 545.

[4] Hall, M. D.; Salam, N. K.; Hellawell, J. L.; Fales, H. M.; Kensler, C. B.; Ludwig J, A.; Szakács G.; Hibbs, D. E.; Gottesman, M. M. J. Med. Chem. 2009 52, 3191.

[5] Padhye, S.; Afrasiabi, Z.; Sinn, E.; Fok J.; Mehta, K.; Rath, N. Inorg. Chem. 2005 44, 1154.

[6] Kowol, C. R.; Trondl, R.; Heffeter, P.; Arion, V. B.; Jakupec, M. A.; Roller, A.; Galanski, M.; Berger, W.; Kep- 
pler, B. K. J. Med. Chem. 2009, 52, 5032.

[7] Bermejo, M. R.; Gonzalez-Noya, A. M.; Pedrido, R.; Romero, M. J.; Vazquez, M. Angew. Chem., Int. Ed. 2005, 44, 4182. [8] Novakovic, S. B.; Bogdanovic, G.; Leovac, V. M. Polyhedron, 2006 25, 1096.

Nfor, E. N.; Esemu, S. N.; Ayimele, G. A.; Ededet, A. E.; Iniama, G. E.; and Offiong, E. O. Bull. Chem. Soc. Ethopia, 2011, 25(3),361.

[9] Kovala-Demertzi, D.; Demertzi, M. A.; Filiou, E.; Pantazaki, A. A.; Yadav, P. N. ; Miller, J. R.; Zheng, Y. and Kyriakidis, D. A. Biometals, 2003, 16, 411.

[10] Bermejo, E.; Carballo, R.; Castineiras, A.; Dominguez, R.; Maichle-Mossmer, C.; Strahle, J.; West, D. X. Polyhedron,

1999, 18, 3695.

West, D. X.; Bain, G. A.; Butcher, R. J.; Jasinski, J. P.; Yu L.; Pozdniakiv, R. Y.; Valdes-Martinez J, Toscano, R. A.; Hernandez-Ortega S. Polyhedron, 1996, 15, 665.

[11] Sreekanth, A.; Joseph, M.; Fun, H-K.; Kurup, M. R. P. Polyhedron, 2006, 25,1408.

Greenwood, N. N. and Earshaw, A. Chemistry of the Elements. $2^{\text {nd }}$ Ed., Elsevier 1997, Butterworth Heinemann.

[12] Huang, D.; Zhang, X.; Chen, C.; Chen, C.; Liu, Q.; Liao, D.; Li, L.; Sun L. Inorg. Chim. Acta, 2003, 353:284.

[13] Usman, A.; Razak, I. A.; Chantrapromma, S.; Fun, H. K.; Sreekanth, S.; Sivakumar, S.; Kurup, M. R. P. Acta Crystallogr. Sect., 2000. C58, 461.

Ferrari M. B.; Fava, G. G.; Pelizzi, C.; Tarasconi, P.; Tori, G. J. Chem. Soc. Dalton Trans. 1987, 227.

Philip, V.; Suni, V.; Kurup, M. R. P.; Nethaji, M. Spectrochim. Acta, 2006 Part A 64:171.

Rapheal, P. F.; Manoj, E.; Kurup, M. R. P. Polyhedron, 2007, 26, 5088.

[14] Sheldrick, G. M. 1998, CrysAlis Pro:( Data collection and data reduction software package Agilent Technologies. SADABS-Program for Empirical Absorption Correction, Göttingen.

[15] SCALE3 ABSPACK: Empirical absorption correction using spherical harmonics.

[16] SHELX includes SHELXS97, SHELXL97: Sheldrick, G. M. Acta Cryst. 2008, A64, 112.

[17] West, D. X.; Bain, G, A.; Butcher, R. J.; Jasinski, J. P.; Yu, L.; Pozdniakiv, R.Y.; Valdes-Martinez, J.; Toscano, R. A.; Hernandez-Ortega, S. Polyhedron 1996,15, 665.

Nfor, E. N.; You, X. Z.; Liu, W. and Iniama, G. Acta Cryst. Sect. E. 2006, E62, m379.

[18] Chan, J.; Thompson, A. L.; Jones, M. W.; Peach, J. M. Inorg. Chim. Acta 2010, 363, 1140.

[19] Sreekanth, A.; Kurup, M. R. P. Polyhedron, 2003, 22,3321 .

[20] Renjusha, S.; Prathapachandra, M. R. Polyhedron, 2008, $27,3294$.
[21] Canadas, M.; Lopez-Torres, E.; Martinez-Arias, A.; Mendiola, M. A.; Sevilla, M. T. Polyhedron, 2000, 19:2059.

[22] Lessa, J. A. ; Reis, D. C. ; Mendes, I. C. ; Speziali, N. L. ; Rocha, L. F. ; Pereira V. R. A. ; Melo, C. M. L. ; Beraldo, H. Polyhedron, $201130,372$. 